\title{
Stratigraphical and geographical distribution of Mississippian (Lower Carboniferous) Crinoidea from Scotland
}

\author{
Thomas W. Kammer ${ }^{1}$ and William I. Ausich ${ }^{2}$ \\ ${ }^{1}$ Department of Geology \& Geography, West Virginia University, Morgantown, West Virginia 26506-6300, USA. \\ E-mail: Thomas.Kammer@mail.wvu.edu \\ ${ }^{2}$ School of Earth Sciences, 155 South Oval Mall, The Ohio State University, Columbus, Ohio 43210, USA. \\ E-mail: ausich@geology.ohio-state.edu
}

\begin{abstract}
A total of 47 genera, in 80 species, of Mississippian, or Lower Carboniferous, crinoids are evaluated from 61 localities in Scotland based on a modern update of the literature, study of museum collections, and new field work. Among the 80 species, 76 are considered valid, with eight requiring new combinations of genus and species names. In addition, one species is considered a nomen dubium, and three can only be assigned at the generic level. Asbian faunas have a moderate generic richness of 13. Brigantian faunas have the highest generic richness at 40 . Arnsbergian faunas have the lowest generic richness at three. There are no Mississippian crinoid faunas in Scotland older than Asbian. The dominant Brigantian crinoid faunas occur in limestones and shales in the shallow shelf marine intervals of Yoredale-style cyclothems. The Asbian faunas occur in shallower, nearshore mudstones and limestones of Yoredale-style cyclothems. The late Viséan (Brigantian) fauna is more similar in overall taxonomic composition to the global record for the Serpukhovian rather than the Viséan. This reflects the establishment of the Late Palaeozoic Crinoid Macroevolutionary Fauna, dominated by advanced cladid crinoids, by the end of the Viséan in Scotland.
\end{abstract}

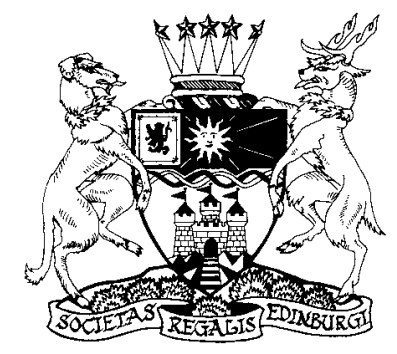

KEY WORDS: Echinodermata, United Kingdom

James Wright (1878-1957), of Kirkcaldy and later Edinburgh, was the key figure in the study of Lower Carboniferous, or Mississippian (Heckel \& Clayton 2005), crinoids in Scotland. His first contribution was in 1911 (Wright 1911-1912) and his endeavours ended with his great monograph on the British Carboniferous Crinoidea (Wright 1950-1960). In between these 'bookends' he published an additional 37 papers and monographs (Webster 2003), including 'The Scottish Carboniferous Crinoidea' (Wright 1939). The overwhelming majority of previous knowledge about Scottish Mississippian crinoids can be attributed to Wright. Some of the more common Scottish taxa were noted by Phillips (1836), Austin \& Austin (1843-1847), and Bather (1920), although Wright (1939) pointed out that many of these were identified incorrectly.

The present paper summarises the current state of knowledge for Scottish Mississippian crinoids based on newer systematic work and revisions since Wright's work, although illustrations of all species discussed are in Wright (1950-1960). This present contribution is part of a larger study on the global evolutionary palaeoecology of Mississippian crinoids. Prerequisite to this analysis is the establishment of accurate generic concepts, facies distributions and temporal ranges of genera. With these data it is planned to test the relationships between generic longevity, eurytopy (environmental breadth) and geographical range within and between the various crinoid clades, in order to assess the patterns of evolutionary success and failure among Late Palaeozoic crinoids. These data for Scotland are presented in the present paper. Previously, these similar data have been presented for England and Wales (Ausich \& Kammer 2006). A subsequent paper for Ireland is planned, which will expand upon Sevastopulo (2002). In addition to genera, major Mississippian crinoid clades are discussed, because these clades have been shown to exhibit characteristic facies distributions (Kammer \& Ausich 1987, Kammer et al. 1998). These include two orders of the subclass Camerata, the orders Diplobathrida and Monobathrida; the subclass Cladida; the subclass Flexibilia; and the subclass Disparida. Within the Cladida, primitive cladids have ramulate arm branching (widely spaced, non-branching side branches), whereas advanced cladids have pinnulate arm branching (closely spaced, non-branching side branches on every arm plate). Subdivision into these clades follows Simms \& Sevastopulo (1993) and Ausich (1996, 1998), and further explanation and definition of these clades can be found in Moore \& Teichert (1978) and Hess et al. (1999).

\section{Mississippian crinoids from Scotland}

Most Mississippian crinoids from Scotland have not received systematic treatment after Wright (1950-1960). Since that time, the Treatise on Invertebrate Paleontology (Moore \& Teichert 1978) has been published, and age-equivalent Mississippian crinoids have been studied in detail in North America (e.g., Burdick \& Strimple 1982; Chesnut \& Ettensohn 1988). Such studies have contributed to a much more rigorous definition of genera. The goal of the present study is to apply modern generic concepts to all Mississippian crinoids from Scotland and to document the facies and temporal distribution of these crinoid genera. Accordingly, the generic assignments, many new, of crinoid species from Scotland are listed in Appendix A. Changes to the generic status of species are 


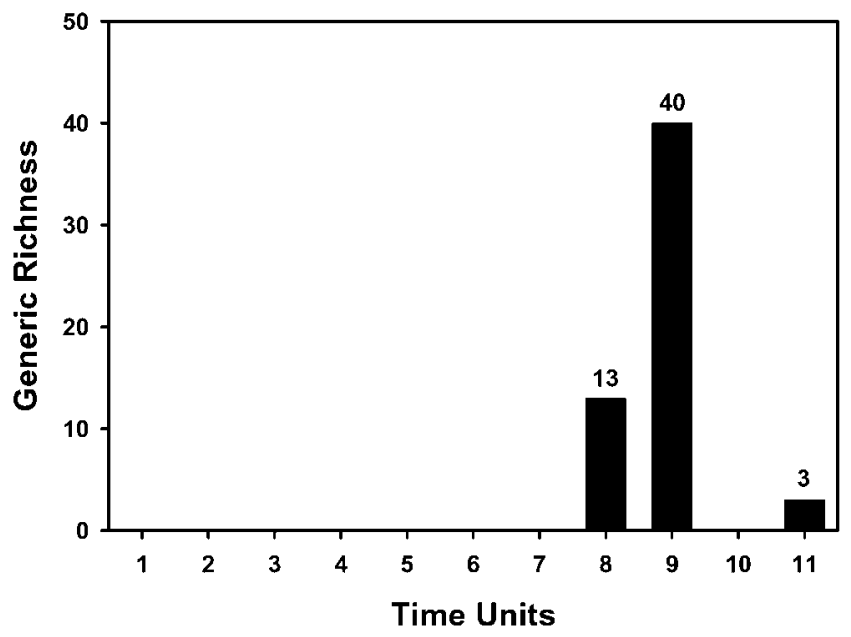

Figure 1 Generic richness of crinoid faunas from Scotland (Table 2) by time unit (Table 1). Compare with data for England and Wales (Ausich \& Kammer 2006, fig. 1).

noted, together with a brief justification. No attempt is made here at species-level synonymy. The taxonomic revisions are based on both updating the literature for Scottish crinoids and study of type specimens from the following museums: National Museum of Scotland (Wright Collection); British Geological Survey, Keyworth; Natural History Museum, London; Sedgwick Museum, Cambridge. Authors of genera are listed in Webster (2003).

In summary, the following changes have been made; please see Appendix A for taxonomic notes. Generic assignments in Wright (1950-1960) are denoted by brackets. These changes include:

Cribanocrinus [Rhodocrinites] baccatus (Wright, 1937), new combination

Litocrinus [Kallimorphocrinus] scoticus contractus (Wright, 1933), new combination

Adinocrinus [Hydreionocrinus] artus (Wright, 1945), new combination

Aphelecrinus [Abrotocrinus] angustatus (Wright, 1934), new combination

Cosmetocrinus [Aphelecrinus] dunlopi (Wright, 1936), new combination

Exaetocrinus [Erisocrinus] carlopsensis (Wright, 1939), new combination

Lanecrinus [Decadocrinus] fifensis (Wright, 1934), new combination

Pelecocrinus [Poteriocrinites?] magnus (Wright, 1937), new combination

One species is recognised as a nomen dubium:

Apographiocrinus? scoticus (Wright, 1942), nomen dubium

\section{Crinoid localities and faunal analysis}

\subsection{Introduction}

Scottish Mississippian crinoids occur only in the Asbian and Brigantian substages of the Viséan and the Arnsbergian substage of the Serpukhovian (Fig. 1 and Table 1, Times 8, 9, and 11). Faunas from all Scottish localities are dominated by advanced cladid crinoids. Their North American equivalents include the late Meramecian and early and late Chesterian, respectively (Burdick \& Strimple 1982; Webster \& Groessen 1990; Jones 1996; Gradstein et al. 2004). Older crinoid faunas, Hastarian through Holkerian (Times 1-7, Table 1), occur in the Mississippian of England, Wales, and Ireland (Sevastopulo 2002; Ausich \& Kammer 2006). Marine localities with crinoids

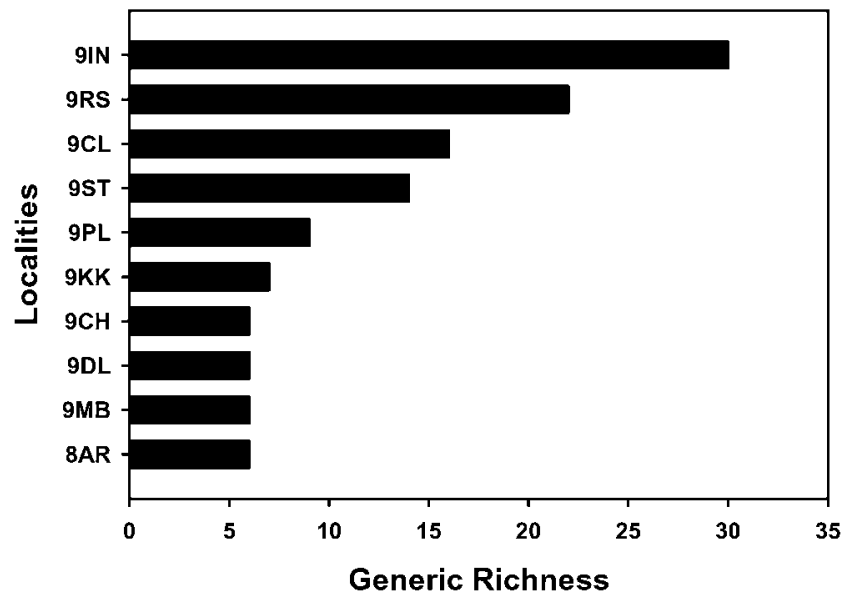

Figure 2 The ten localities with the highest crinoid generic richness in Scotland; 9IN =Invertiel; 9RS=Roscobie; 9CL=Carlops; 9ST = Seafield Tower; 9PL=Penton Linns; $9 \mathrm{KK}=$ Kirkaldy; $9 \mathrm{CH}=$ Chapel; 9DL $=$ Duloch; 9MB $=$ Macbiehill; $8 \mathrm{AR}=$ Ardross; (Appendices A and $\mathrm{B})$.

are essentially confined to the Midland Valley and Southern Borders (Appendix B). These two areas are the Midland Valley Basin and Northumberland Basin, respectively, separated by the Southern Uplands (Read et al. 2002). Detailed information on specific localities and their stratigraphy is given in Forsyth \& Chisholm (1977), MacGregor (1996), Purnell \& Cossey (2004), and Whyte (2004).

The oldest Mississippian fossiliferous marine rocks in Scotland are of late Viséan (Asbian and Brigantian) age and occur in the Strathclyde Group, formerly the Calciferous Sandstone Measures (Wilson 1974, 1989; Browne et al. 1999). Thus, there are no crinoids older than Asbian (Time 8, Table 1) in Scotland. Older Carboniferous deposits in Scotland are represented by rocks of terrestrial and volcanic origin (Browne et al. 1999; Read et al. 2002).

\subsection{Asbian, Time 8}

In the Midland Valley of Scotland, the Asbian consists of all but the uppermost formation (Pathhead Formation) of the Strathclyde Group (Browne et al. 1999). Formations are composed of sedimentary and volcanic rocks, including coal and lacustrine or lagoonal oil shale. The Strathclyde Group is dominantly fluvial and lacustrine in origin, with sporadic marine beds that are better developed in the east (Read et al. 2002). Marine beds are referred to as marine bands of which there are several in the Strathclyde Group, particularly in the Pittenweem Formation, including: Macgregor Marine Bands (St Andrews Castle Marine Band, Pittenweem Marine Band, Witch Lake Marine Band, etc.), West Braes Marine Band, Balmore Marine Band, and Ardross Limestone (Wilson 1974, 1989; Browne et al. 1999). Most of these marine bands have a low generic richness of crinoids; Ardross (8AR) in Fife, with six genera, has the greatest richness (Fig. 2 and Appendix B).

Asbian rocks in central Scotland are predominantly nonmarine clastics ranging from mudstones to sandstones and include lacustrine or lagoonal oil shales, coals, seatearths, and ironstones (Wilson 1989) and represent fluvial, lacustrine, and deltaic deposits (Read et al. 2002). The marine rocks include limestones, mudstones, and silty mudstones. These rocks comprise Yoredale-type cyclothems in which marine rocks are succeeded by upward-coarsening fluvial-deltaic deposits capped by palaeosols and coals (Browne et al. 1999; Read et al. 2002; Kassi et al. 2004). These cyclothems resulted from glacioeustatic changes in sea level associated with 
Brigantian (Time 9), Scotland, $n=33$
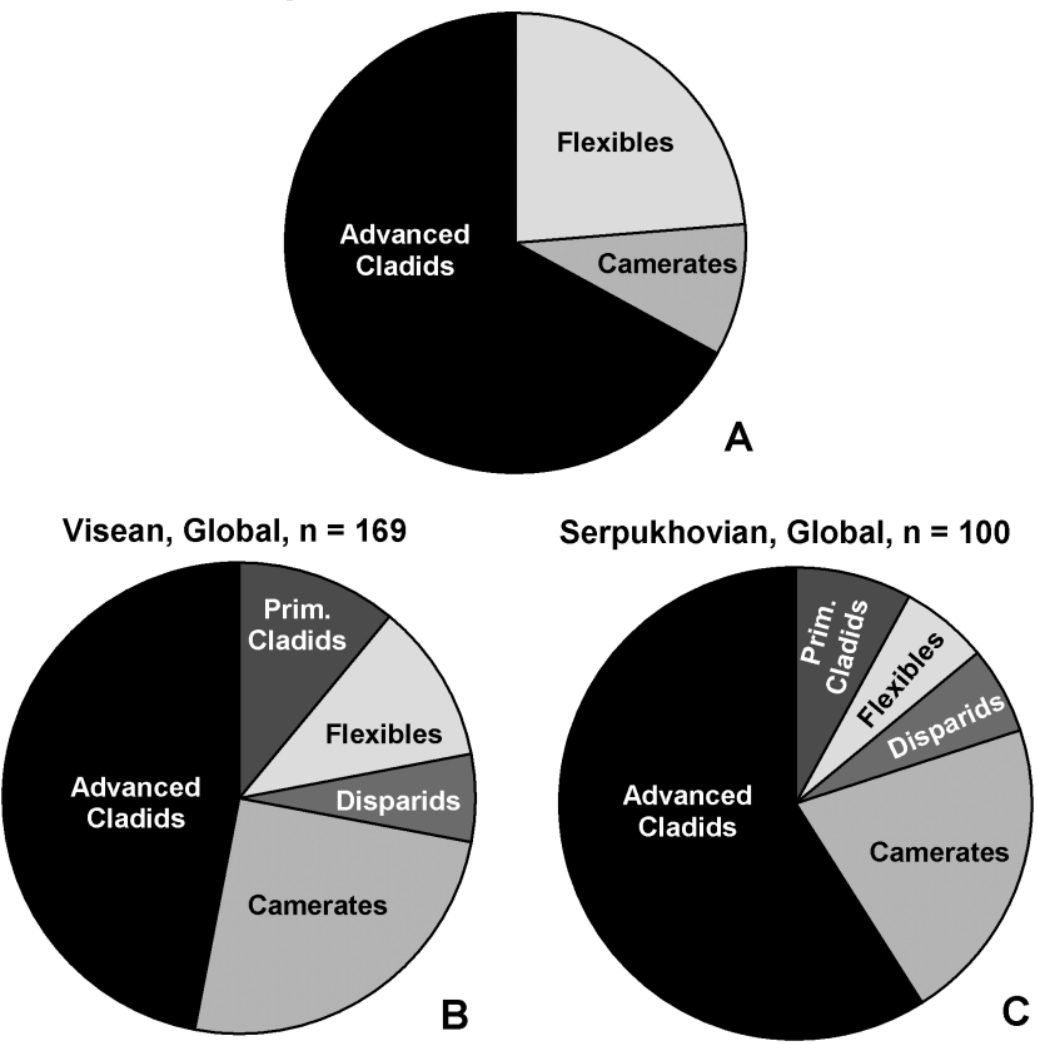

Figure 3 A. Pie chart showing proportions of macrofossil crinoid genera during the Brigantian (late Viséan, Time 9) in Scotland. Compare with both the Viséan and Serpukhovian of the world in B and C (Kammer \& Ausich 2006).

Gondwanan glaciers (Smith \& Read 2000; Wright \& Vanstone 2001). We examined the MacGregor Marine Bands between Ansthruther and Pittenweem in Fife. The marine bands are dolomudstones containing bioclastic lag deposits, which appear to be storm deposits. They are interbedded with oil shales of probable lagoonal origin (Read et al. 2002, p. 264). This, together with tidal laminations within the immediately overlying siltstones, indicates close proximity of the marine bands to a low-energy shoreline.

At the St Andrews shore section, approximately $300 \mathrm{~m}$ of the Asbian Pittenweem Formation are exposed, including three marine bands that total approximately $9 \mathrm{~m}$ in thickness, or just 3\% of the formation. Marine bands include: West Sands Marine Band (or Cuniger Rock Marine Band), Witch Lake Marine Band, and St Andrews Castle Marine Band (Forsyth \& Chisholm 1977; Browne et al. 1999). The Witch Lake Marine Band consists of approximately $3.6 \mathrm{~m}$ of mudstone and includes the $15 \mathrm{~cm}$ crinoidal limestone Encrinite Bed near the centre (Forsyth \& Chisholm 1977), which may record maximum water depth.

The Witch Lake Marine Band contains crinoids, brachiopods, molluscs, and bryozoans (Forsyth \& Chisholm 1977). It most likely represents shallow marine deposition associated with a rapid glacioeustatic rise in sea level that transgressed fluvial-deltaic environments (Read et al. 2002; Kassi et al. 2004). The presence of both crinoids and bryozoans indicates fully marine, stenohaline conditions (Kammer \& Lake 2001). Crinoid species richness from the Encrinite Bed is three: Tubulusocrinus doliolus (Wright 1936) (see Kammer \& Ausich 2007), Ureocrinus bockschii (Geinitz) (Wright 1952a, p. 112), and Mantikosocrinus wrighti (Yakovlev \& Ivanov) (as Dicromyocrinus geminatus (Trautschold) in Wright 1952a, p. 111).
Asbian crinoid richness is relatively low, with only 13 genera (Fig. 1). These Asbian faunas are composed primarily of advanced cladids, with the diplobathrid camerate Cribanocrinus and two flexibles.

\subsection{Brigantian, Time 9}

In the Scottish Midland Valley, the Brigantian consists of the Pathhead Formation at the top of the Strathclyde Group and the overlying Lower Limestone Formation of the Clackmannan Group (Browne et al. 1999; Whyte 2004). Marine horizons are more common in the Pathhead Formation than in the underlying formations of the Strathclyde Group, with the Pathhead Formation resembling the overlying Lower Limestone Formation (Read et al. 2002, p. 266) Crinoids occur in the Lower Ardross Limestone, Upper Ardross Limestone, and St Monance White Limestone of the Pathhead Formation and the various limestone members of the Lower Limestone Formation including (in stratigraphical order) the Hurlet Limestone or St Monance Brecciated Limestone $(3.5 \mathrm{~m})$, the St Monance Little Limestone $(0.6 \mathrm{~m})$, the Charlestown Main Limestone $(1.5 \mathrm{~m})$, the Seafield Marine Band or Main Hosie Limestone, the Mid Kinniny Limestone or Mid Hosie Limestone $(0.6 \mathrm{~m})$, and the Upper Kinniny Limestone or Top Hosie Limestone $(0.3 \mathrm{~m})$ (Forsyth \& Chisholm 1977; Browne et al. 1999). The Lower Limestone Formation is at least $225 \mathrm{~m}$ thick, yet the limestones total only $6.5 \mathrm{~m}$, or about $3 \%$ of the formation. Like the Strathclyde Group, the Lower Limestone Formation is composed of Yoredale-type cyclothems in which marine rocks are succeeded by upward-coarsening fluvial-deltaic deposits capped by paleosols and coals (Browne et al. 1999; Read et al. 2002; Kassi et al. 2004). However, the greater amount of limestone, commonly packstones and grainstones, in the marine zones of 
Table 1 Chronostratigraphical definition of time units for British crinoid occurrences; based on Vaughan's (1905) coral/brachiopod zones, Leeder (1992), Jones (1996)², Hance et al. (2002), and Gradstein et al. (2004) ${ }^{3}$. Vaughan's (1905) coral/brachiopod zones are included because many of Wright's (1950-1960) localities were dated on this basis

\begin{tabular}{lllcrrr}
\hline Time Unit & $\begin{array}{c}\text { Western } \\
\text { Europe }\end{array}$ & \multicolumn{1}{c}{ Chronostratigraphy } & $\begin{array}{c}\text { Coral/Brach } \\
\text { Zone }^{1}\end{array}$ & $\begin{array}{c}\text { Starting Time } \\
\text { m.y. }{ }^{3}\end{array}$ & $\begin{array}{c}\text { Duration } \\
\text { m.y. }{ }^{3}\end{array}$ & $\begin{array}{c}\text { Duration } \\
\text { m.y. }^{2}\end{array}$ \\
\hline 11 & E2 & Serpukhovian, Arnsbergian & & $323 \cdot 4$ & $>3 \cdot 0$ & $>3 \cdot 0$ \\
10 & E1 & Serpukhovian, Pendleian & & $326 \cdot 4$ & $3 \cdot 0$ & $5 \cdot 0$ \\
9 & V3c & Viséan, Brigantian & D2 & $328 \cdot 6$ & $2 \cdot 2$ & $3 \cdot 5$ \\
8 & V3b & Viséan, Asbian & D1 & $332 \cdot 5$ & $3 \cdot 9$ & $2 \cdot 0$ \\
7 & V2b,V3a & Viséan, Holkerian & S2 & $339 \cdot 2$ & $6 \cdot 7$ & $4 \cdot 5$ \\
6 & V2a, V1b & Viséan, Arundian & S1 & $342 \cdot 8$ & $3 \cdot 6$ & $6 \cdot 5$ \\
5 & V1a & Viséan, upper Chadian & C2 & $345 \cdot 3$ & $2 \cdot 5$ & $1 \cdot 5$ \\
4 & Tn3c & Tournaisian, lower Chadian & C1 & $345 \cdot 8$ & $0 \cdot 5$ & $1 \cdot 0$ \\
3 & Tn3a,b,c & Tournaisian, Ivorian & Z & $349 \cdot 0$ & $3 \cdot 2$ & $4 \cdot 0$ \\
2 & Tn2 & Tournaisian, Hastarian & K2 & & Total Hastarian \\
1 & Tn1b & Tournaisian, Hastarian & K1 & $359 \cdot 2$ & $10 \cdot 2$ & $6 \cdot 0$ \\
& & & Total Duration, m.y. & $41 \pm 2$ & $>37 \cdot 0$ \\
\hline
\end{tabular}

the Lower Limestone, as compared to the more argillaceous marine zones of the Strathclyde Group, suggests a more open marine setting farther offshore due to more widespread marine transgressions at this time. Read et al. (2002, p. 275) reported that 'the Lower Limestone Formation is the interval with the strongest marine influences during the Scottish Carboniferous.' This more open marine setting is probably the reason for the greater number of genera in the Brigantian (40) versus the Asbian (13) (Fig. 1) and the fact that $89 \%$ of the crinoid localities are from the Brigantian (Appendix B). Kammer \& Ausich (2006) argued that crinoids flourished in open marine settings away from salinity fluctuations. As during the Asbian, these cyclothems resulted from glacioeustatic changes in sea level associated with Gondwanan glaciers (Smith \& Read 2000; Wright \& Vanstone 2001).

Of the 61 localities in Scotland with identified crinoids, 54 are Brigantian (Time 9) in age. Nine of these localities have six or more genera (Fig. 2, Appendix B). Localities with 10 or more genera are all in the Lower Limestone Formation and include: Invertiel, Fife (30); Roscobie, Fife (22); Carlops, Scottish Borders (16); and Seafield Tower, Fife (14). Stratigraphical details for Invertiel, Roscobie, and Seafield Tower (part of the Kinghorn Coast) are described in Whyte (2004).

The Brigantian faunas of Scotland and adjacent England include the youngest occurrences of genera that are typical of the Tournaisian and Viséan of North America. Perhaps most notable is the genus Cribanocrinus. This is the youngest report of this genus, and the only younger reports of the order Diplobathrida are from the Serpukhovian of Russia and Algeria (Arendt 2002; Webster et al. 2004). In addition, the following genera have their youngest occurrences in these faunas: Adinocrinus, Allocatillocrinus, Blothrocrinus, Mespilocrinus, Pelecocrinus and Wachsmuthicrinus.

\subsection{Pendleian and Arnsbergian, Times 10 and 11}

The Pendleian (Time 10) in Scotland is composed of the Limestone Coal Formation and the lower part of the Upper Limestone Formation (Browne et al. 1999; Read et al. 2002). The majority of the Upper Limestone Formation is Arnsbergian. No crinoids have been reported from the Limestone Coal Formation. Crinoids have been reported from the marine horizons in the middle of the Upper Limestone Formation at only one locality, Garpel Water, Muirkirk, East Ayrshire (11GW, Appendix B) (Whyte 2004, p. 100-2). These include Platycrinites muirkirkensis (Wright, 1956, p. 291), Allagecrinus garpelensis (Wright, 1952a, p. 142), and
Ureocrinus bockschii (Wright, 1952a, p. 112), all presumably of Arnsbergian age. Woodocrinus whytei (Wright, 1951b) also occurs at Garpel Water (locality 9GW, Appendix B) in the Lower Limestone Formation.

\section{Discussion and conclusions}

With a richness of 40 genera, the crinoid fauna of the Brigantian (Time 9) dominates the Mississippian of Scotland. With just a few exceptions, the 13 genera of the Asbian (Time 8 ) are essentially a subset of the Brigantian (Table 2), although many of the species are different. The species listed in Appendix A are all valid species according to the rules of the International Code of Zoological Nomenclature (International Commission on Zoological Nomenclature 1999). However, in reviewing all these species for their correct generic assignments, it was clear that many of these species are subjective synonyms, and if synonymised, would occur in both the Asbian and Brigantian. Revision of species-level taxonomy is beyond the scope of the present paper, but it does not appear that there was a significant evolutionary turnover between the Asbian and Brigantian.

Rather, it is hypothesised that the jump in generic richness from 13 to 40 between the Asbian and Brigantian (Fig. 1, Times 8 and 9) reflects the more widespread occurrence of preferred environments during the Brigantian. The drop to only three genera in the Arnsbergian (Time 11) appears to reflect the subsequent loss of these environments during deposition of the Upper Limestone Formation, which is limited in exposure and has reported crinoids only at Garpel Water (locality 11GW, Appendix B).

The Brigantian fauna with 40 genera includes seven species of microcrinoids (Table 2). This is a relatively large number of microcrinoids and reflects the deliberate search by Wright (1950-1960) for these small forms. In general, microcrinoids are reported in few studies because they involve the microscopic examination of sediment residues (Lane \& Sevastopulo 1982). The remaining 33 genera are all macrocrinoids, which are the type of crinoids almost always reported in the literature. These genera are dominated by advanced cladids (67\%), with subordinate numbers of flexibles $(24 \%)$, and camerates $(9 \%)$; there are no disparids or primitive cladids (Table 2). When compared with a global database for the Viséan and Serpukhovian (Fig. 3), it is readily apparent that the Brigantian fauna is more similar to the Serpukhovian than the Viséan, even though it is of late Viséan age. This is because 
Table 2 Seriated temporal distribution of western European crinoid genera. Occurrences in Scotland indicated by 1; additional occurrences in Western Europe by $\mathbf{X}$. ? denotes questionable occurrences in Scotland. Microcrinoids are separated, because of probable sampling biases

\begin{tabular}{|c|c|c|c|c|c|c|c|c|c|c|c|}
\hline \multirow[t]{2}{*}{ Genera } & \multicolumn{11}{|c|}{ Time Units } \\
\hline & 1 & 2 & 3 & 4 & 5 & 6 & 7 & 8 & 9 & 10 & 11 \\
\hline \multicolumn{12}{|c|}{ Diplobathrid Camerates } \\
\hline Cribanocrinus & & & & $\mathbf{X}$ & $\mathbf{X}$ & & & 1 & 1 & & \\
\hline Gilbertsocrinus & & & $\mathbf{X}$ & $\mathbf{X}$ & $\mathbf{X}$ & & & & & & \\
\hline Rhodocrinites & & & $\mathbf{X}$ & & & & & & & & \\
\hline \multicolumn{12}{|c|}{ Monobathrid Camerates } \\
\hline Camptocrinus & & & & & & & & & 1 & & \\
\hline Ectocrinus & & & & & & & & $\mathbf{X}$ & $\mathbf{x}$ & & \\
\hline Acrocrinus & & & & & & & $\mathbf{X}$ & & & & \\
\hline New Genus B & & & & $\mathbf{X}$ & $\mathbf{X}$ & & & & & & \\
\hline Eumorphocrinus & & & & $\mathbf{X}$ & $\mathbf{X}$ & & & & & & \\
\hline Pimlicocrinus & & & & $\mathbf{X}$ & & & & & & & \\
\hline New Genus A & & & & $\mathbf{X}$ & & & & & & & \\
\hline Brahmacrinus & & & & $\mathbf{X}$ & & & & & & & \\
\hline Pleurocrinus & & & $\mathbf{X}$ & $\mathbf{X}$ & $\mathbf{X}$ & & & $\mathbf{X}$ & $\mathbf{x}$ & $\mathbf{X}$ & \\
\hline Thinocrinus & & & $\mathbf{X}$ & $\mathbf{X}$ & $\mathbf{X}$ & & & & & & \\
\hline Actinocrinites & & & $\mathbf{X}$ & $\mathbf{X}$ & $\mathbf{x}$ & & & & & & \\
\hline Amphoracrinus & & & $\mathbf{X}$ & $\mathbf{X}$ & $\mathbf{x}$ & & & & & & \\
\hline Iotacrinus & & & $\mathbf{X}$ & $\mathbf{X}$ & & & & & & & \\
\hline Aryballocrinus & & & $\mathbf{X}$ & & & & & & & & \\
\hline Physetocrinus & & & $\mathbf{X}$ & & & & & & & & \\
\hline Dialutocrinus & & & $\mathbf{X}$ & & & & & & & & \\
\hline Platycrinites & & & $\mathbf{X}$ & $\mathbf{X}$ & $\mathbf{X}$ & $\mathbf{X}$ & & $\mathbf{X}$ & 1 & $\mathbf{X}$ & 1 \\
\hline Dichocrinus & & & $\mathbf{X}$ & $\mathbf{x}$ & & & & & & & \\
\hline \multicolumn{12}{|l|}{ Disparids } \\
\hline Halysiocrinus? & & & & & $\mathbf{X}$ & & & & & & \\
\hline Synbathocrinus & & & $\mathbf{X}$ & $\mathbf{X}$ & $\mathbf{X}$ & & & $\mathbf{x}$ & & & \\
\hline \multicolumn{12}{|l|}{ Primitive Cladids } \\
\hline Barycrinus & & & & $\mathbf{X}$ & $\mathbf{X}$ & & & & & & \\
\hline Edapocrinus & & & & $\mathbf{x}$ & & & & & & & \\
\hline Cyathocrinites & & & $\mathbf{X}$ & $\mathbf{X}$ & $\mathbf{X}$ & & & & & & \\
\hline
\end{tabular}

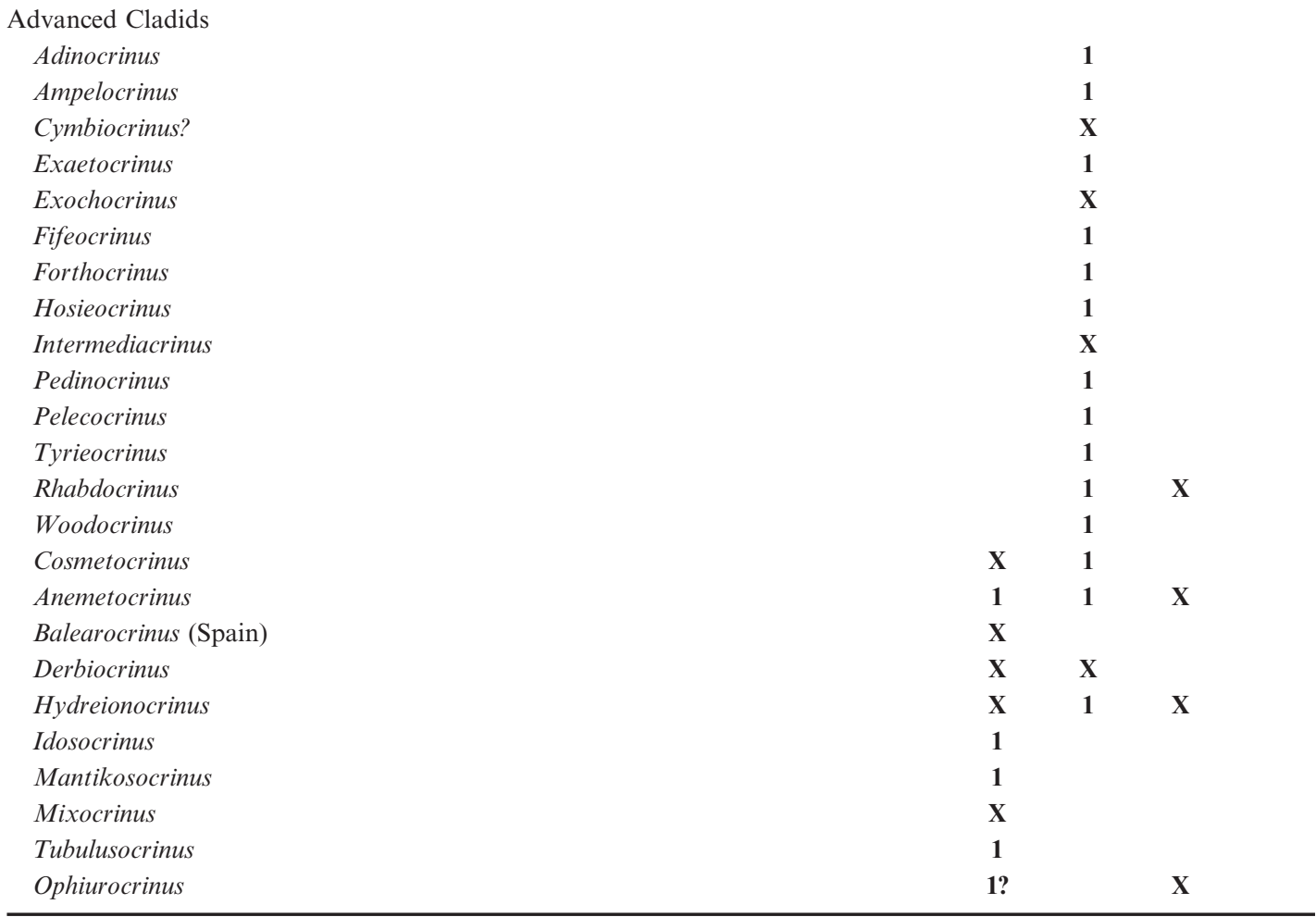


Table 2 Continued.

\begin{tabular}{|c|c|c|c|c|c|c|c|c|c|c|c|}
\hline \multirow[t]{2}{*}{ Genera } & \multicolumn{11}{|c|}{ Time Units } \\
\hline & 1 & 2 & 3 & 4 & 5 & 6 & 7 & 8 & 9 & 10 & 11 \\
\hline Parazeacrinites & & & & & & & & $\mathbf{X}$ & 1 & & \\
\hline Scotiacrinus & & & & & & & & 1 & 1 & $\mathbf{X}$ & \\
\hline Ureocrinus & & & & & & & & 1 & 1 & $\mathbf{X}$ & 1 \\
\hline Phanocrinus & & & & & & $\mathbf{X}$ & $\mathbf{X}$ & 1 & 1 & & \\
\hline Hypselocrinus & & & & & $\mathbf{X}$ & $\mathbf{X}$ & $\mathbf{X}$ & 1 & & & \\
\hline Aphelecrinus & & & & $\mathbf{X}$ & $\mathbf{X}$ & & $\mathbf{X}$ & 1 & 1 & & \\
\hline Springericrinus & & & & $\mathbf{X}$ & & & & & & & \\
\hline Culmicrinus & & & $\mathbf{X}$ & & & & & $\mathbf{X}$ & & & \\
\hline Gilmocrinus & & & $\mathbf{x}$ & & $\mathbf{X}$ & & & & & & \\
\hline Borucrinus & & & $\mathbf{X}$ & $\mathbf{X}$ & $\mathbf{X}$ & & $\mathbf{X}$ & & & & \\
\hline Abrotocrinus & & & $\mathbf{X}$ & & & & & & & & \\
\hline Erincrinus & & & $\mathbf{X}$ & & & & & & & & \\
\hline Fiannacrinus & & & $\mathbf{X}$ & & & & & & & & \\
\hline Glamorganocrinus & & & $\mathbf{x}$ & & & & & & & & \\
\hline Graphiocrinus & & & $\mathbf{x}$ & & & & & & & & \\
\hline Holcocrinus & & & $\mathbf{X}$ & & & & & & & & \\
\hline Maevecrinus & & & $\mathbf{X}$ & & & & & & & & \\
\hline Mendipocrinus & & & $\mathbf{x}$ & & & & & & & & \\
\hline Paracosmetocrinus & & & $\mathbf{x}$ & & & & & & & & \\
\hline Scytalocrinus & & & $\mathbf{x}$ & & & & & & 1 & & \\
\hline Bollandocrinus & & & $\mathbf{X}$ & $\mathbf{X}$ & & & & $?$ & ? & & \\
\hline Gaelicrinus & & & $\mathbf{X}$ & & & & & & & & \\
\hline Sostronocrinus & & & $\mathbf{X}$ & & & & & & & & \\
\hline Poteriocrinites & & & $\mathbf{X}$ & $\mathbf{X}$ & $\mathbf{X}$ & & & & & & \\
\hline Blothrocrinus & & & $\mathbf{X}$ & $\mathbf{X}$ & & & & 1 & 1 & & \\
\hline Lanecrinus & & & & & $?$ & & & & 1 & & \\
\hline \multicolumn{12}{|l|}{ Flexibles } \\
\hline Ainacrinus & & & & & & & & & 1 & & \\
\hline Artichthyocrinus & & & & & & & & & 1 & & \\
\hline Caldenocrinus & & & & & & & & & 1 & & \\
\hline Wachsmuthicrinus & & & & & & & & & 1 & & \\
\hline Amphicrinus & & & & & & & & & 1 & & \\
\hline Aexitrophocrinus & & & & & & & & 1 & $1 ?$ & & \\
\hline Enascocrinus & & & & & & & & 1 & 1 & & \\
\hline Onychocrinus & & & & & & $\mathbf{X}$ & $\mathbf{X}$ & $\mathbf{X}$ & 1 & & \\
\hline Dieuryocrinus & & & & $\mathbf{X}$ & & & & & & & \\
\hline Euryocrinus & & & & $\mathbf{X}$ & & & & & & & \\
\hline Forbesiocrinus & & & $\mathbf{X}$ & & & & & & & & \\
\hline Mespilocrinus & & & $\mathbf{X}$ & $\mathbf{X}$ & & & & & 1 & & \\
\hline Taxocrinus & $\mathbf{X}$ & & $\mathbf{X}$ & $\mathbf{X}$ & $\mathbf{X}$ & & & & & & \\
\hline \multicolumn{12}{|l|}{ Disparid Microcrinoids } \\
\hline Allagecrinus & & & & & & & & & 1 & & 1 \\
\hline Allocatillocrinus & & & & & & & & & 1 & & \\
\hline Kallimorphocrinus & & & & & & & & & 1 & & \\
\hline Litocrinus & & & & & & & & $\mathbf{X}$ & 1 & & \\
\hline Thaminocrinus & & & & & & & & & 1 & & \\
\hline \multicolumn{12}{|l|}{ Cladid Microcrinoids } \\
\hline Abrachiocrinus & & & & & & & & $\mathbf{x}$ & & & \\
\hline Aulodesocrinus & & & & & & & & & 1 & & \\
\hline Carlopsocrinus & & & & & & & & & 1 & & \\
\hline Cydonocrinus & & & & & & & & & $\mathbf{X}$ & & \\
\hline Lageniocrinus & & & & & & & & $\mathbf{X}$ & $\mathbf{X}$ & & \\
\hline Sycocrinites & & & & & & & & $\mathbf{X}$ & & & \\
\hline Generic Richness & 0 & 0 & 0 & 0 & 0 & 0 & 0 & 13 & 40 & 0 & 3 \\
\hline
\end{tabular}


there are a greater number of camerate genera in the early Viséan than the late Viséan, producing a higher average for the total Viséan as the Middle Palaeozoic Macroevolutionary Crinoid Fauna was waning (Ausich et al. 1994). By the Serpukhovian, advanced cladids formed the majority of crinoid taxa when the Late Palaeozoic Macroevolutionary Crinoid Fauna was established (Kammer \& Ausich 2006). The Brigantian fauna is also notable for the large percentage of flexibles $(23 \%)$, which is higher than the global record for the Viséan (11\%) and the Serpukhovian (6\%) (Fig. 3). The reason for the greater number of flexibles is unknown, but probably reflects the occurrence of the preferred environments for flexibles during the Brigantian in Scotland.

\section{Acknowledgements}

We thank Lyall Anderson (National Museum of Scotland), Mike Howe (British Geological Survey), Andrew Smith and David Lewis (Natural History Museum, London), and Dan Pemberton and Rod Long (Sedgwick Museum, Cambridge) for access to collections and assistance with locality information. In particular, Lyall Anderson was very helpful with requests for information. Ruth Robinson and Tony Prave (University of St Andrews) kindly showed us numerous outcrops in Fife. George Sevastopulo (Trinity College, Dublin) and Andrew Smith (Natural History Museum, London) made important improvements to the final manuscript. This research was supported by the US National Science Foundation (EAR-02059068 and EAR-0206307).

\section{Appendix A}

List of species assignments to genus without regard to species level synonymies; key references and page numbers are provided. Where a species has been reassigned, a brief explanation is given. Only those species of each genus reported from Scotland are included. See Webster (2003) for complete bibliographic citations. Species localities are keyed to Appendix B. Time ranges by genera are listed in Table 2 .

\section{DIPLOBATHRIDS}

\section{CRIBANOCRINUS}

Cribanocrinus (né Rhodocrinites) baccatus (Wright, 1937); Wright, 1958, p. 313, n. comb. Occurrence: 9BE, 9BT, 9CQ, 9EL, 9FH, 9HH, 9IN, 9MB, 9RS, 9SM, 9ST. The globose calyx shape and lack of plate sculpturing ally this species with Cribanocrinus.

Cribanocrinus sp. 8AR, 9BR, 9BS, 9CL, 9CU, 9KK, 9PL.

\section{MONOBATHRIDS}

CAMPTOCRINUS

Camptocrinus compressus Wright, 1937; Wright, 1958, p. 307. Occurrence: 9IN.

\section{PLATYCRINITES}

Platycrinites conglobatus (Wright, 1937); Wright, 1956, p. 277. Occurrence: 9IN.

Platycrinites crassiconus (Wright, 1937); Wright, 1956, p. 278. Occurrence: 9CA, 9CL, 9DU, 9IN, 9RS, 9ST.

Platycrinites muirkirkensis Wright, 1956, p. 291. Occurrence: $11 \mathrm{GW}$.

Platycrinites invertielensis (Wright, 1942); Wright, 1956, p. 293. Occurrence: 9IN.

Platycrinites spiniger (Wright, 1937); Wright, 1956, p. 292. Occurrence: 9CL, 9DU, 9IN, 9KK, 9OM, 9RS, $11 \mathrm{GW}(?)$.

\section{DISPARIDS}

\section{ALLAGECRINUS}

Allagecrinus austinii Carpenter \& Etheridge, 1881; Wright, 1952a, p. 139. Occurrence: 9CL, 9HO, 9IN.

Allagecrinus garpelensis Wright, 1932; Wright, 1952a, p. 142. Occurrence: $11 \mathrm{GW}$.

\section{ALLOCATILLOCRINUS}

Allocatillocrinus scoticus (Wright, 1933); Wright, 1952a, p. 147. Occurrence: 9IN.

\section{KALLIMORPHOCRINUS}

Kallimorphocrinus elongatus (Wright, 1932); Wright, 1952a, p. 146. Occurrence: 9AM, 9DA, 9DR, 9DU, 9HO, 9IN, 9LI, 9LM, 9MD, 9PW, 9SK.

\section{LITOCRINUS}

Litocrinus extensus (Wright, 1952a, p. 146); Lane \& Sevastopulo, 1982, p. 258. Occurrence: 9CL.

Litocrinus scoticus (Wright, 1932); Wright, 1952a, p. 143; Lane \& Sevastopulo, 1982, p. 258. Occurrence: 9CL, 9CO, 9DU, 9IN, 9LM, 9PW, 9RS.

Litocrinus (né Kallimorphocrinus) scoticus contractus (Wright, 1933) n. comb. Occurrence: 9CL. Litocrinus scoticus contractus is a subspecies because it has a narrower aboral cup. The species was assigned to Litocrinus by Lane \& Sevastopulo (1982).

\section{THAMINOCRINUS}

Thaminocrinus biplex (Wright, 1932); Wright, 1952a, p. 142; Strimple \& Watkins, 1969, p. 217. Occurrence: 9CL, 9IN.

\section{CLADIDS}

\section{ADINOCRINUS}

Adinocrinus (né Hydreionocrinus) artus (Wright, 1945); Wright, 1951b, p. 88, n. comb. Occurrence: 9IN, 9RS, 9ST. These are all cups that have small, isolated basals with the radials in contact with the infrabasals. They are low, saucershaped, with a basal concavity. They are closely comparable to Adinocrinus nodosus (Wachsmuth \& Springer 1886) from the early Viséan of North America (Kammer \& Ausich 1994).

\section{AMPELOCRINUS}

Ampelocrinus plumosus Wright, 1951b, p. 93. Occurrence: 9PL.

\section{ANEMETOCRINUS}

Anemetocrinus biserialis Wright, 1938; Wright, 1950, p. 24. Occurrence: 9CH, 9CL, 9CS, 9CT, 9DL, 9HM, 9IN, 9MB, 9PP, 9RS, 9ST.

Anemetocrinus ardrossensis Wright, 1938; Wright, 1951a, p. 27. Occurrence: 8AR.

Anemetocrinus wilsoni Wright, 1952b, 1960, p. 330. Occurrence: $8 / 9 \mathrm{TH}$.

Anemetocrinus covensis (Wright, 1934), 1951a, p. 28. Occurrence: $8 \mathrm{CH}$.

Anemetocrinus pentonensis (Wright, 1934), 1951a, p. 28. Occurrence: 9CS, 9PL.

Anemetocrinus sp. Occurrence: 9RS.

\section{APHELECRINUS}

Aphelecrinus (né Abrotocrinus) angustatus (Wright, 1934); Wright, 1951b, p. 69, n. comb. Occurrence: 8AR, 8ES.

This species has a conical cup. Thus, it cannot be an Abrotocrinus, which has a low bowl-shaped cup. It has the characters of Aphelecrinus: first primbrachial axillary on all rays, two isotomous bifurcations per ray, three anals, and 
a pentagonal column. Kirk (1944, p. 198) reported that $A$. mundus has a pentagonal stem, although the Treatise stated that the column is typically round, but $A$. mundus and $A$. oweni are subpentagonal. It appears that Aphelecrinus has a round to pentagonal column. The holotype has a large anal sac with rectangular plates (Wright, 1951b, pl. 31, fig. 8 and text-fig. 36). Aphelecrinus has a large anal sac (Moore et al. 1978, fig. 428.2c).

Aphelecrinus dilatatus Wright, 1945; Wright, 1951a, p. 45. Occurrence: 9IN, 9RS.

Aphelecrinus roscobiensis Wright, 1945; Wright, 1951a, p. 46. Occurrence: 9RS.

Aphelecrinus parvus Wright, 1945; Wright, 1951a, p. 46. Occurrence: 9IN

Aphelecrinus sp. Wright, 1951a, p. 47. Occurrence: 9RS.

\section{APOGRAPHIOCRINUS}

Apographiocrinus? scoticus (Wright, 1942); Wright, 1952a, p. 119, nomen dubium. Occurrence: 9CL.

These are all tiny specimens only a few $\mathrm{mm}$ in size. Wright's (1952a, pl. 35, figs 7-10) photographs failed to state the magnification, which was about $\times 10$ or $\times 20$. The cups are poorly preserved, and the arms are missing. The cups have a very small single anal plate, the anal $\mathrm{X}$, which is unlike the much larger single anal plate of Apographiocrinus. Although the arms are not preserved, Wright (1952a) stated that primibrachial 2 is axillary, which is unlike Apographiocrinus where primibrachial 1 is axillary. The cups are crushed but are apparently low. They do not fit either Apographiocrinus or Cymbiocrinus; no other genera come close. It seems best to consider this taxon as a nomen dubium.

\section{AULODESOCRINUS}

Aulodesocrinus parvus Wright, 1942; Wright, 1951b, p. 73. Occurrence: 9IN.

\section{BLOTHROCRINUS}

Blothrocrinus thorntonensis Wright, 1952b; Wright, 1960, p. 331. Occurrence: $8 / 9 \mathrm{TH}$.

\section{CARLOPSOCRINUS}

Carlopsocrinus bullatus Wright, 1933; Wright, 1954a, p. 181. Occurrence: 9CL.

\section{COSMETOCRINUS}

Cosmetocrinus (né Aphelecrinus) dunlopi (Wright, 1936); Wright, 1951a, p. 43, n. comb. Occurrence: 9PL, 9RS.

The holotype has three bifurcations in line per ray on both the $\mathrm{C}$ ray and the apparent A ray (Wright, 1951a, pl. 11, fig. 1). Aphelecrinus has only two bifurcations in line per ray, whereas Cosmetocrinus has two or three.

\section{EXAETOCRINUS}

Exaetocrinus (né Erisocrinus) carlopsensis (Wright, 1939); Wright, 1951b, p. 101, n. comb. Occurrence: 9CL.

This is a juvenile; the photographs in Wright (1951b, pl. 30, figs 11,12$)$ are magnified $\times 5$. The only known arm plates are the first primibrachial on each arm, which are axillary and extremely long as is common among juveniles (Peters \& Lane 1990). Wright placed this species in Erisocrinus because of the lack of anal plates, but that is a Pennsylvanian-age genus. Unlike Erisocrinus, this species has its infrabasals visible in side view. This species fits well in Exaetocrinus Strimple \& Watkins, 1969 (Moore et al. 1978, p. T705), which was reported from the Viséan of Scotland and Morocco, as well as the Pennsylvanian of North America. It is unclear why Moore et al. (1978) reported this genus from
Scotland because neither Strimple \& Watkins (1969, p. 181) nor Webster (2003) listed this genus from Scotland.

\section{FIFEOCRINUS}

Fifeocrinus tielensis (Wright, 1936); Wright, 1951a, p. 42. Occurrence: 9AK, 9BA, 9BH, 9CT, 9CW, 9IN, 9RS.

\section{FORTHOCRINUS}

Forthocrinus lepidus Wright, 1942; Wright, 1951b, p. 72. Occurrence: 9AK, 9CL, 9IN.

\section{HOSIEOCRINUS}

Hosieocrinus caledonicus (Wright, 1936); Wright, 1952a, p. 137. Occurrence: 9ST.

\section{HYDREIONOCRINUS}

Hydreionocrinus formosus Wright, 1939; Wright, 1951b, p. 89. Occurrence: 9SM.

Hydreionocrinus amplus Wright, 1951b, p. 84. Occurrence: 9IN, 9RS.

\section{HYPSELOCRINUS}

Hypselocrinus ardrossensis Wright, 1951a, p. 33. Occurrence: $8 \mathrm{ES}$.

\section{IDOSOCRINUS}

Idosocrinus bispinosus Wright, 1954b; Wright, 1960, p. 332. Occurrence: 8/9TH.

Idosocrinus tumidus Wright, 1954b; Wright, 1960, p. 332. Occurrence: 8LB.

\section{LANECRINUS}

Lanecrinus (né Decadocrinus) fifensis (Wright, 1934); Wright, 1951b, p. 59, n. comb. Occurrence: 9CL, 9IN, 9RS.

This is a Lanecrinus as it has three anals, primibrachial one axillary, 10 arms, and zig-zag brachials, all characters of the genus (Kammer \& Ausich 1993). It is very similar to $L$. fountainensis (Worthen 1882) from the Genevievian, lower Monteagle Limestone (Burdick \& Strimple 1982, p. 117). These two species are both from the Brigantian and may even be conspecific. The small size of L. fifensis strongly suggests these are juveniles, so the elongated brachials may be a juvenile feature.

\section{MANTIKOSOCRINUS}

Mantikosocrinus wrighti (Yakovlev \& Ivanov, 1956), Wright, 1952a, p. 111 as Dicromyocrinus geminatus (Trautschold, 1867). Occurrence: 8SA.

According to Moore et al. (1978), Dicromyocrinus geminatus (Trautschold) of Wright (1952a) equals D. wrighti of Yakovlev and Ivanov, which Strimple (1966) referred to Mantikosocrinus, a genus that also occurs in the Chesterian of the USA.

\section{OPHIUROCRINUS}

Ophiurocrinus? arbiglandensis (Wright, 1934); Wright, 1950, p. 22. Occurrence: 8AS.

This does have some of the characters of Ophiurocrinus, including five atomous arms, but the cup is low conical/high bowl-shaped rather than high conical as typical for the genus. The brachials are also cuneate rather than rectangular. Wright (1950) stated that the posterior is normal with three anal plates, but the holotype does not have the posterior exposed. Thus, this species is questionably assigned to Ophiurocrinus. It also resembles Gilmocrinus with the arms being similar to $G$. dactyloides in Ausich \& 
Sevastopulo (2001, pl. 10, figs 2, 7, 8), but the cup is not high conical as in Gilmocrinus.

\section{PARAZEACRINITES}

Parazeacrinites konincki (Bather, 1912); Wright, 1952a, p. 107. Occurrence: 9AB, 9BE, 9BF, 9BG, 9BH, 9CH, 9CL, 9CS, 9CT, 9CU, 9CW, 9DA, 9DL, 9HO, 9IN, 9KK, 9MB, 9OB, 9OM, 9PP, 9RH, 9RS, 9RY, 9TS.

\section{PEDINOCRINUS}

Pedinocrinus clavatus (Wright, 1937); Wright, 1951b, p. 77. Occurrence: 9RS.

\section{PELECOCRINUS}

Pelecocrinus (né Poteriocrinites?) magnus (Wright, 1937); Wright, 1950, p. 9, n. comb. Occurrence: 9CH, 9HM, 9IN, 9RS, 9ST.

This species consists of large, thin, isolated cup plates of an advanced cladid as shown by the angustary radial facets with a distinct fulcral ridge. The thin plates are unlike Poteriocrinites. The thin plates and angustary facets are similar to Parisocrinus and Pellecrinus, but these genera lack a distinct fulcral ridge. Instead, the radial facets are very similar to Pelecocrinus fiscellus (Meek \& Worthen 1870) from the Tournaisian Burlington Limestone of Iowa, and the cup plates are similar to Pelecocrinus insignatus Kirk, 1941 also from the Burlington Limestone. This is apparently the youngest occurrence of Pelecocrinus.

\section{PHANOCRINUS}

Phanocrinus ardrossensis (Wright, 1934); Wright, 1951b, p. 97. Occurrence: 8AR, 8ES.

Phanocrinus calyx (M'Coy, 1849); Wright, 1951b, p. 94. Occurrence: 9AK, 9BG, 9BH, 9CC, 9CH, 9CU, 9CW, 9DA, 9DL, 9IN, 9LM, 9PL, 9PP, 9RS, 9RY, 9ST, 9TS.

Phanocrinus scoticus (de Koninck, 1858); Wright, 1951b, p. 96. Occurrence: 9LM.

Phanocrinus gordoni Wright, 1939; Wright, 1951b, p. 99. Occurrence: 9CL, 9IN, 9OM, 9ST.

Phanocrinus stellaris (Wright, 1934); Wright, 1951b, p. 98. Occurrence: 9CH, 9IN, 9RS, 9SM, 9ST.

Phanocrinus? altus Wright, 1942; Wright, 1951b, p. 101. Occurrence: $9 \mathrm{CL}$.

\section{RHABDOCRINUS}

Rhabdocrinus pentonensis (Wright, 1937); Wright, 1950, p. 16. Occurrence: 9PL.

Rhabdocrinus scotocarbonarius (Wright, 1937); Wright, 1950, p. 13. Occurrence: 9BA, 9BH, 9CH, 9CW, 9IN, 9KN, 9LM, 9RS, 9ST.

\section{SCOTIACRINUS}

Scotiacrinus ardrossensis Wright, 1945; Wright, 1951b, p. 76. Occurrence: 8AR.

Scotiacrinus tyriensis (Wright, 1937); Wright, 1951b, p. 75. Occurrence: 9IN, 9RS.

\section{SCYTALOCRINUS}

Scytalocrinus seafieldensis Wright, 1948; Wright, 1951a, p. 34. Occurrence: 9ST.

\section{TUBULUSOCRINUS}

Tubulusocrinus (né Ureocrinus) doliolus (Wright, 1936); Wright, 1952a, p. 116; Kammer \& Ausich, 2007. Occurrence: 8SA. This species has five atomous arms and a tubular, uncalcified anal sac (Kammer \& Ausich, 2007). It has previously been assigned to Hydriocrinus, then Ulocrinus, and finally Ureocrinus (Wright, 1952a). Hydriocrinus has an essentially identical cup, but it has more than five arms with bifurcations at primibrachial one or higher and is only known from the upper Carboniferous (Middle Pennsylvanian) (Moore et al. 1978, p. T643). Ulocrinus has a thick-plated conical cup and 10 arms, and is also only known from the Middle and Upper Pennsylvanian (upper Carboniferous) (Moore et al. 1978, p. T701). Tubulusocrinus doliolus is similar to Ureocrinus bockschii, (also from the Encrinite Bed at St Andrews) in having five arms (Wright \& Strimple 1945). However, it is distinct in having a conical cup composed of thin plates, whereas Ureocrinus has a high-bowl, globose cup with thick plates, and is constricted at the top of the cup, rather than at the proximal primibrachials (Moore et al. 1978, p. T701).

\section{TYRIEOCRINUS}

Tyrieocrinus laxus Wright, 1945; Wright, 1952a, p. 117. Occurrence: 9CL, 9CT, 9DL, 9IN, 9RH, 9RS, 9ST.

\section{UREOCRINUS}

Ureocrinus bockschii (Geinitz, 1846); Wright, 1952a, p. 112. Occurrence: 8/9TH, 9AB, 9BE, 9BH, 9BR, 9BS, 9CB, 9CC, 9CL, 9CM, 9CO, 9CP, 9CQ, 9CR, 9CT, 9CU, 9CW, 9DA, 9DL, 9DO, 9GI, 9IN, 9KK, 9MB, 9OM, 9PL, 9RS, 9SH, 9SM, 9ST, 9TB, 9TQ, 9TS, 11GW.

\section{WOODOCRINUS}

Woodocrinus gravis Wright, 1936; Wright, 1951b, p. 53. Occurrence: 9IN, 9RS.

Woodocrinus liddesdalensis Wright, 1936; Wright, 1951b, p. 52. Occurrence: 9PL.

Woodocrinus pentonensis Wright, 1951b, p. 56. Occurrence: 9PL.

Woodocrinus whytei Wright, 1936; Wright, 1951b, p. 57. Occurrence: 9GW.

\section{FLEXIBLES}

\section{AEXITROPHOCRINUS}

Aexitrophocrinus jaekeli (Moore \& Plummer, 1940); Wright, 1954a, p. 153; Moore, 1978, p. T195, fig. 165.1. Occurrence: 8AR.

Aexitrophocrinus? strimplei (Wright, 1946); Wright, 1954a, p. 156; Webster, 2003. Occurrence: 9IN, 9MB, 9ST.

This was a new combination by Webster (2003). This species is known only from cups with up to two primibrachials, the second being axillary. The cup is most similar to Aexitrophocrinus (Miss.) and Synerocrinus (Penn.). The CD basal extends to the top of the radials and even beyond in one specimen (Wright 1954a, pl. 43, fig. 15). The stem attachment area does not cover most of the basals. Because the arms are lacking on known specimens, this species is questionably placed in Aexitrophocrinus.

\section{AINACRINUS}

Ainacrinus smithi (Wright, 1934); Wright, 1954a, p. 151. Occurrence: 9AK.

\section{AMPHICRINUS}

Amphicrinus scoticus Springer, 1920; Wright, 1954a, p. 149. Occurrence: 9AB, 9AK, 9BA, 9BG, 9CH, 9CL, 9CU, 9DL, 9HM, 9IN, 9LD, 9RS, 9ST, 9TS.

\section{ARTICHTHYOCRINUS}

Artichthyocrinus springeri Wright, 1923; Wright, 1954a, p. 160. Occurrence: 9HM, 9IN, 9KK, 9RS, 9TL. 


\section{CALDENOCRINUS}

Caldenocrinus curtus Wright, 1946; Wright, 1954a, p. 158. Occurrence: 9IN, 9RS, 9ST.

\section{ENASCOCRINUS}

Enascocrinus redesdalensis (Wright, 1952b); Wright, 1954a, p. 154. Occurrence: 8/9RD, 8/9TH.

\section{MESPILOCRINUS}

Mespilocrinus depressus Wright, 1936; Wright, 1954a, p. 180. Occurrence: 9KK, 9SM.
Mespilocrinus pringlei Wright, 1954a, p. 178. Occurrence: 9BS, 9CL, 9IN, 9KK, 9MB, 9SM.

ONYCHOCRINUS

Onychocrinus liddelensis Wright, 1954a, p. 171. Occurrence: 9PL.

Onychocrinus wrighti Springer, 1920; Wright, 1954a, p. 170. Occurrence: 9IN, 9KK.

WACHSMUTHICRINUS

Wachsmuthicrinus ponderosus Springer, 1920; Wright, 1954a, p. 166. Occurrence: 9VT.

\section{Appendix B}

Localities (61) in Scotland with reported crinoid crown and calyx occurrences with current county and approximate British Grid Coordinates. The number in the code is the age (Table 1). Genus richness in parentheses at the end of each locality name. $9 \mathrm{GW}$ and $11 \mathrm{GW}$ are the same locality but indicate the Lower Limestone Formation and the Upper Limestone Formation, respectively.

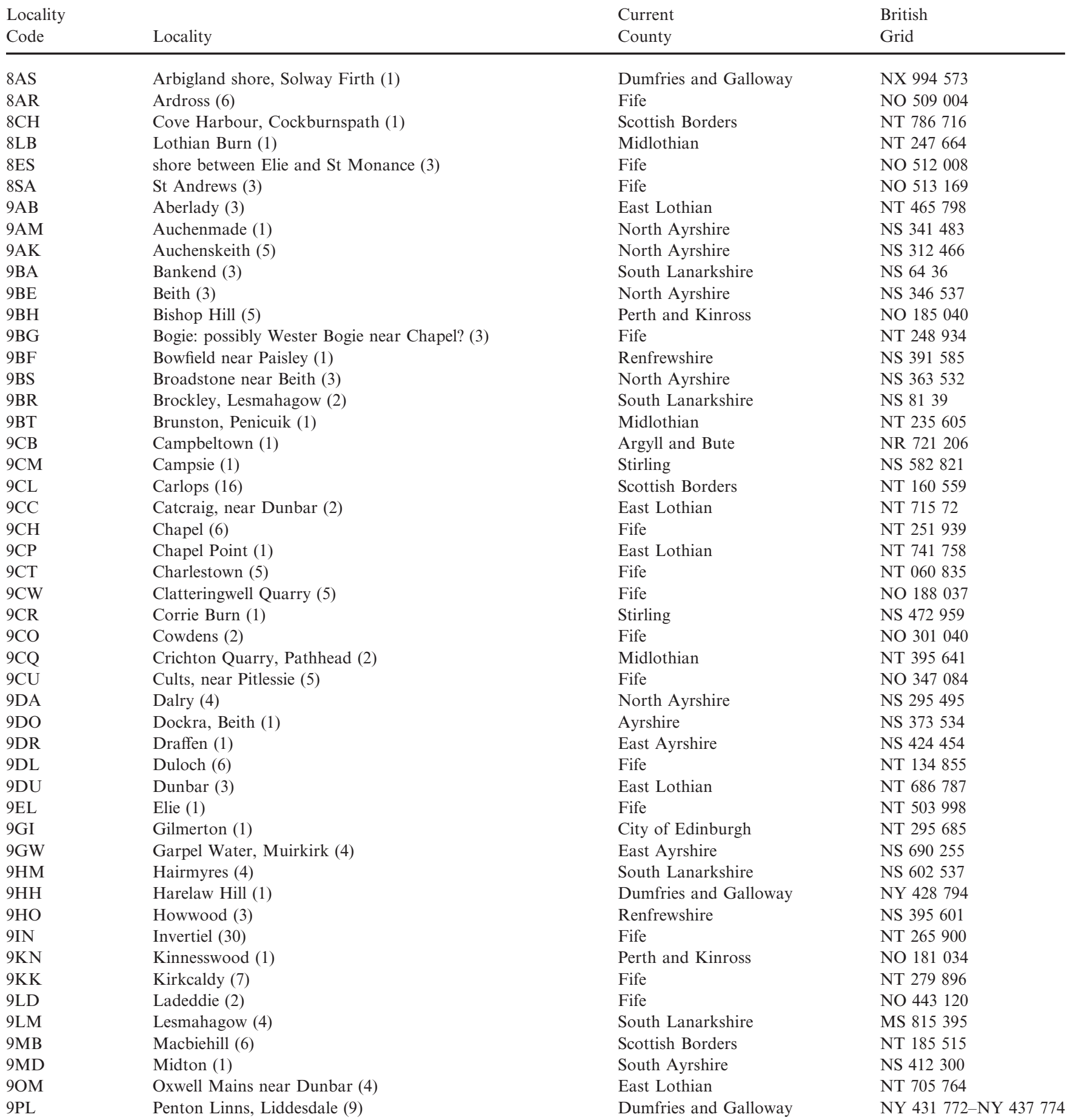




$\begin{array}{ll}\text { 9PW } & \text { Poniel Water (2) } \\ \text { 9PP } & \text { Potmetal Plantation NW of Kirkcaldy (3) } \\ \text { 9RS } & \text { Roscobie (22) } \\ \text { 9ST } & \text { Seafield Tower or Seafield Shore (14) } \\ \text { 9SK } & \text { Skateraw (1) } \\ \text { 9SM } & \text { St Monance (5) } \\ \text { 9TS } & \text { Teasses, near Largo (4) } \\ \text { 9TL } & \text { Thornliebank (1) } \\ \text { 9TB } & \text { Tiel Burn, west of Kirkcaldy (1) } \\ \text { 9TQ } & \text { Trearne Quarry (1) } \\ \text { 9VT } & \text { Vale of the Tweed, between Roxburgh and Kelso (1) } \\ \text { 8/9TH } & \text { Thornton Burn (5) } \\ 11 \mathrm{GW} & \text { Garpel Water, Muirkirk (4) }\end{array}$

\section{References}

Arendt, Yu. A. 2002. Early Carboniferous echinoderms of the Moscow region. Paleontological Journal 36, Suppl. 2, S115-S184.

Ausich, W. I. 1996. Crinoid plate circlet homologies. Journal of Paleontology 70, 955-64.

Ausich, W. I. 1998. Early phylogeny and subclass division of the Crinoidea (phylum Echinodermata). Journal of Paleontology 72, 499-510.

Ausich, W. I. \& Kammer, T. W. 2006. Stratigraphical and geographical distribution of Mississippian (Lower Carboniferous) Crinoidea from England and Wales. Proceedings of the Yorkshire Geological Society 56, 91-109.

Ausich, W. I. \& Sevastopulo, G. D. 2001. The Lower Carboniferous (Tournaisian) crinoids from Hook Head, County Wexford, Ireland. Monograph of the Palaeontographical Society 617.

Ausich, W. I., Kammer, T. W. \& Baumiller, T. K. 1994. Demise of the Middle Paleozoic crinoid fauna: a single extinction event or a rapid faunal turnover? Paleobiology 20, 345-61.

Austin, T., Sr. \& Austin, T., Jr. 1843-1847. A monograph on Recent and fossil Crinoidea, with figures and descriptions of some Recent and fossil allied genera 1, 2, 1-32, pl. 1-4, frontispiece (1843); 3 , 33-48, pl. 5-6 (1844); 4, 49-64, pl. 7-8 (1845); 5, 65-80, pl. 9-10 (1846); 6-8, 81-128, pl. 11-16 (1847). London and Bristol: private subscription.

Bather, F. A. 1912. Notes on Hydreionocrinus. Transactions of the Edinburgh Geological Society 10, 61-76.

Bather, F. A. 1920. Some British specimens of Ulocrinus. Transactions of the Glasgow Geological Society (1916-1917) 16, 207-19.

Browne, M. A. E., Dean, M. T., Hall, I. H. S., McAdam, A. D., Monro, S. K. \& Chisholm, J. I. 1999. A lithostratigraphical framework for the Carboniferous rocks of the Midland Valley of Scotland. British Geological Survey Research Report RR/99/07.

Burdick, D. W. \& Strimple, H. L. 1982. Genevievian and Chesterian crinoids of Alabama. Geological Survey of Alabama, Bulletin 121.

Carpenter, P. H. \& Etheridge, R. Jr. 1881. Contributions to the study of the British Palaeozoic crinoids - No. 1. On Allagecrinus, the representative of the Carboniferous Limestone Series. Annals and Magazine of Natural History, series 5 7, 281-98.

Chesnut, D. R. \& Ettensohn, F. R. 1988. Hombergian (Chesterian) echinoderm paleontology and paleoecology, south-central Kentucky. Bulletins of American Paleontology 95, 1-102.

Forsyth, I. H. \& Chisholm, J. I. 1977. The Geology of East Fife. Memoir of the Geological Survey of Great Britain, Sheet 41 and part of 49 (Scotland). Edinburgh: HMSO.

Geinitz, H. B. 1846. Grundriss der Versteinerungskunde, 522-60. Dresden und Leipzig: Arnoldische Buchhandlung.

Gradstein, F., Ogg, J. \& Smith, A. 2004. A Geologic Time Scale 2004. Cambridge: Cambridge University Press.

Hance, L., Devuyst, F.-X. \& Poty, E. 2002. Sequence stratigraphy of the Belgian Lower Carboniferous - tentative correlation with the British Isles. In Hills, L. V., Henderson, C. M. \& Bamber, E. W. (eds) Carboniferous and Permian of the World. Canadian Society of Petroleum Geologists, Memoir 19, 41-51.

Heckel, P. \& Clayton, G. 2005. Official names for the Carboniferous System. Geology Today 21, 213-14.

Hess, H., Ausich, W. I., Brett, C. E. \& Simms, M. J. 1999. Fossil Crinoids. Cambridge: Cambridge University Press.

International Commission on Zoological Nomenclature. 1999. International Code of Zoological Nomenclature, fourth edn.

$\begin{array}{ll}\text { South Lanarkshire } & \text { NS } 833341 \\ \text { Fife } & \text { NT } 235918 \\ \text { Fife } & \text { NT } 091930 \\ \text { Fife } & \text { NT } 280885 \\ \text { East Lothian } & \text { NT } 735752 \\ \text { Fife } & \text { NO } 524014 \\ \text { Fife } & \text { NO } 405077 \\ \text { East Renfrewshire } & \text { NS } 549592 \\ \text { Fife } & \text { NT } 245901 \\ \text { North Ayrshire } & \text { NS } 373533 \\ \text { Scottish Borders } & \text { NT } 685325 \\ \text { East Lothian } & \text { NT } 739740 \\ \text { East Ayrshire } & \text { NS } 690255\end{array}$

International Trust for Zoological Nomenclature. London: The Natural History Museum.

Jones, P. J. 1996. Carboniferous (Chart 5). In Young, G. C., Laurie, J. R. (eds) An Australian Phanerozoic Timescale, 110-26. Melbourne: Oxford University Press.

Kammer, T. W., Ausich, W. I. \& Baumiller, T. K. 1998. Evolutionary significance of differential species longevity in OsageanMeramecian (Mississippian) crinoid clades. Paleobiology 24, $155-76$.

Kammer, T. W. \& Ausich, W. I. 1987. Aerosol suspension feeding and current velocities: distributional controls for late Osagean crinoids. Paleobiology 13, 379-95.

Kammer, T. W. \& Ausich, W. I. 1993. Advanced cladid crinoids from the Middle Mississippian of the east-central United States: Intermediate-grade calyces. Journal of Paleontology 67, 614-39.

Kammer, T. W. \& Ausich, W. I. 1994. Advanced cladid crinoids from the Middle Mississippian of the east-central United States: Advanced-grade calyces. Journal of Paleontology 68, 339-51.

Kammer, T. W. \& Ausich, W. I. 2006. The 'Age of Crinoids': A Mississippian biodiversity spike coincident with widespread carbonate ramps. Palaios 21, 238-48.

Kammer, T. W. \& Ausich, W. I. 2007. Soft-tissue preservation of the hind gut in a new genus of cladid crinoid from the Mississippian (Asbian) at St Andrews, Scotland. Palaeontology 50, 951-59.

Kammer, T. W. \& Lake, A. M. 2001. Salinity ranges of Late Mississippian invertebrates of the central Appalachian basin. Southeastern Geology 40, 99-116.

Kassi, A. M., Weir, J. A., McManus, J. \& Browne, M. A. E. 2004. Lithofacies and sedimentary cycles within the late Dinantian (late Brigantian) of Fife and East Lothian: is a sequence stratigraphical approach valid? Transactions of the Royal Society of Edinburgh: Earth Sciences 94 (for 2003), 95-113.

Kirk, E. 1941. Four new genera of Mississippian Crinoidea Inadunata. Journal of Paleontology 15, 81-88.

Kirk, E. 1944. Aphelecrinus, a new inadunate crinoid genus from the Upper Mississippian. American Journal of Science 242, 190-203.

Koninck, L. G., de. 1858. On several Palaeozoic crinoids new to England and Scotland. The Geologist 1, 146-49, 178-84.

Lane, N. G. \& Sevastopulo, G. D. 1982. Growth and systematic revision of Kallimorphocrinus astrus, a Pennsylvanian microcrinoid. Journal of Paleontology 56, 244-59.

Leeder, M. R. 1992. Dinantian. In Duff, P. McL. D. \& Smith, A. J. (eds) Geology of England and Wales, 207-38. London: The Geological Society.

MacGregor, A. R. 1996. Fife and Angus Geology, an Excursion Guide. Edinburgh: Pentland Press.

M'Coy, F. 1849. On some new Palaeozoic Echinodermata. Annals and Magazine of Natural History series 2 3, 244-54.

Meek, F. B. \& Worthen, A. H. 1870. Descriptions of new Carboniferous fossils from the western States. Proceedings of the Academy of Natural Sciences of Philadelphia 1870, 137-72.

Moore, R. C. 1978. Flexibilia. In Moore, R. C. \& Teichert, C. (eds) Treatise on Invertebrate Paleontology, Part T, Echinodermata 2, Crinoidea 2, T759-T812. Boulder, Colorado and Lawrence, Kansas: Geological Society of America and University of Kansas Press.

Moore, R. C., Strimple, H. L. \& Lane, N. G. 1978. Suborder Poteriocrinina Jaeckel, 1918. In Moore, R. C. \& Teichert, C. (eds) Treatise on Invertebrate Paleontology, Part T, Echinodermata 2, Crinoidea 2, T630-T754. Boulder, Colorado and Lawrence, 
Kansas: Geological Society of America and University of Kansas Press.

Moore, R. C. \& Plummer, F. B. 1940. Crinoids from the Upper Carboniferous and Permian strata in Texas. University of Texas Publication 3945, 1-468.

Moore, R. C. \& Teichert, C. (eds) 1978. Treatise on Invertebrate Paleontology, Part T, Echinodermata 2, Crinoidea. Boulder, Colorado and Lawrence, Kansas: Geological Society of America and University of Kansas Press.

Peters, J. \& Lane, N. G. 1990. Ontogenetic adaptations in some Pennsylvanian crinoids. Journal of Paleontology 64, 427-35.

Phillips, J. 1836. Illustrations of the geology of Yorkshire, or a description of the strata and organic remains. The Mountain Limestone districts, Part 2, 2nd edn., 203-208. London: John Murray.

Purnell, M. A. \& Cossey, P. J. 2004. Northumberland Trough. In Cossey, P. J., Adams, A. E., Purnell, M. A., Whiteley, M. J., Whyte, M. A. \& Wright, V. P. (eds) British Lower Carboniferous Stratigraphy, 107-66. Peterborough, UK: Joint Nature Conservation Committee.

Read, W. A., Browne, M. A. E., Stephenson, D. \& Upton, B. G. J. 2002. Carboniferous. In Trewin, N. H. (ed.) The Geology of Scotland, 251-99. London: The Geological Society.

Sevastopulo, G. D. 2002. Fossil 'Lillies of the ocean' and other echinoderms from Carboniferous rocks of Ireland. John Jackson Memorial Lecture 2002. The Royal Dublin Society Occasional Papers in Science No. 25.

Simms, M. J. \& Sevastopulo, G. D. 1993. The origin of articulate crinoids. Palaeontology 36, 91-109.

Smith, L. B. \& Read, J. F. 2000. Rapid onset of Late Paleozoic glaciation on Gondwana: evidence from Upper Mississippian strata of the Midcontinent, United States. Geology 28, 279-82.

Springer, F. 1920. The Crinoidea Flexibilia. Smithsonian Institution Publication 2501.

Strimple, H. L. 1966. New species of cromyocrinids from Oklahoma and Arkansas. Oklahoma Geology Notes 26, 3-12.

Strimple, H. L. \& Watkins, W. T. 1969. Carboniferous crinoids of Texas with stratigraphic implications. Palaeontographica Americana 6 (40), 139-275.

Trautschold, H. 1867. Einige crinoideen und andere Thierreste des Jungeren Bergkalks im Gouvernment Moskau. Bulletin de la Societie Imperial Naturalistes de Moscou 15, (3-4), 1-49.

Vaughan, A. 1905. The palaeontological sequence in the Carboniferous Limestone of the Bristol area. Quarterly Journal of the Geological Society of London 61, 181-307.

Wachsmuth, C. \& Springer, F. 1886. Revision of the Palaeocrinoidea, Pt. 3, Sec. 2, Discussion of the classification and relations of the brachiate crinoids, and conclusion of the generic descriptions. Proceedings of the Academy of Natural Sciences of Philadelphia $1885,64-226$.

Webster, G. D. 2003. Bibliography and index of Paleozoic crinoids, coronates, and hemistreptocrinoids, 1758-1999. Geological Society of America, Special Paper 363 (CD). URL: crinoid.gsajournals.org/crinoidmod

Webster, G. D., Maples, C. G., Sevastopulo, G. D., Frest, T. \& Waters, J. A. 2004. Carboniferous (Viséan-Moscovian) echinoderms from the Béchar basin area of western Algeria. Bulletins of American Paleontology 368.

Webster, G. D. \& Groessen, E. 1990. Conodont subdivision of the Lower Carboniferous. Courier Forschung-Institute Senckenberg 130, 31-40.

Whyte, M. A. 2004. Midland Valley Basin. In Cossey, P. J., Adams, A. E., Purnell, M. A., Whiteley, M. J., Whyte, M. A. \& Wright, V. P. (eds) British Lower Carboniferous Stratigraphy, 13-105. Peterborough, UK: Joint Nature Conservation Committee.
Wilson, R. B. 1974. A study of the Dinantian marine faunas of south-east Scotland. Bulletin of the Geological Survey of Great Britain 46, 35-65.

Wilson, R. B. 1989. A study of the Dinantian marine macrofossils of central Scotland. Transactions of the Royal Society of Edinburgh: Earth Sciences 80, 91-126.

Worthen, A. H. 1882. Descriptions of fifty-four new species of crinoids from the Lower Carboniferous limestones and Coal Measures of Illinois and Iowa. Illinois State Museum of Natural History Bulletin 1, 3-38.

Wright, J. 1911-12. On the crinoids from the Lower Carboniferous limestones of Invertiel Fife. Transactions of the Edinburgh Geological Society 10, 49-60.

Wright, J. 1923. Artichthyocrinus, n. g., a flexible crinoid from the Carboniferous limestone of Fife. Geological Magazine 60, 481-90.

Wright, J. 1932. The Scottish species of Allagecrinus. Geological Magazine 69, 337-66.

Wright, J. 1933. Two new crinoids from the Scottish Carboniferous Limestones, with notes on the Allagecrinidae. Geological Magazine 70, 193-208.

Wright, J. 1934. New Scottish and Irish fossil crinoids. Geological Magazine 71, 241-68.

Wright, J. 1936. New Scottish Carboniferous crinoids. Geological Magazine 73, 385-412.

Wright, J. 1937. Scottish Carboniferous crinoids. Geological Magazine 74, 385-411.

Wright, J. 1938. Anemetocrinus N.G. a five-armed poteriocrinid from the Lower Carboniferous limestones of Scotland. Geological Magazine 75, 337-46.

Wright, J. 1939. The Scottish Carboniferous Crinoidea. Transactions of the Royal Society of Edinburgh 60, no. 1, pt. 1, 1-78.

Wright, J. 1942. New British Carboniferous crinoids. Geological Magazine 79, 269-83.

Wright, J. 1945. Tyrieocrinus (gen. nov.) and Scotiacrinus (gen. nov.) and seven new species of inadunate crinoids from the Carboniferous limestones of Scotland and Yorkshire. Geological Magazine 82, 114-25.

Wright, J. 1946. Caldenocrinus gen. nov. and related Scottish crinoids. Geological Magazine 83, 33-8.

Wright, J. 1948. Scytalocrinus seafieldensis sp. nov. and a rare Ureocrinus from the Carboniferous limestones of Fife; with notes on a blastoid and two crinoids from the Carboniferous limestone of the Clitheroe area. Geological Magazine 85, 48-52.

Wright, J. 1950-1960. The British Carboniferous Crinoidea. Palaeontographical Society, Monograph 1(1), 1-24, (1950); 1(2), 25-46, (1951a); 1(3), 47-102, (1951b); 1(4), 103-48, (1952a); 1(5), 149-90, (1954a); 2(1), (191-254), 1955a; 2(2), 255-72, (1955b); 2(3), 273306, (1956); 2(4), 307-28, (1958); 2(5), 329-47, (1960).

Wright, J. 1952b. Crinoids from Thornton Burn, East Lothian. Geological Magazine 89, 320-27.

Wright, J. 1954b. Idosocrinus gen. nov. and other crinoids from Thornton Burn, East Lothian. Geological Magazine 91, 167-70.

Wright, J. \& Strimple, H. L. 1945. Mooreocrinus and Ureocrinus gen. nov., with notes on the family Cromyocrinidae. Geological Magazine 82, 221-9.

Wright, V. P. \& Vanstone, S. D. 2001. Onset of Late Paleozoic glacio-eustasy and the evolving climates of low latitude areas. Journal of the Geological Society, London 158, 579-82.

Yakovlev, N. N. \& Ivanov, A. P. 1956. Morskie lilii i blastoidei kamennougolnykh i permskikh otlozhenii SSSR [Marine crinoids and blastoids of the Carboniferous and Permian deposits of Russia]. Vsesoyuznogo Nauchno-Issledovatelskii Geologicheskogo Institut Trudy 11, 1-142. 